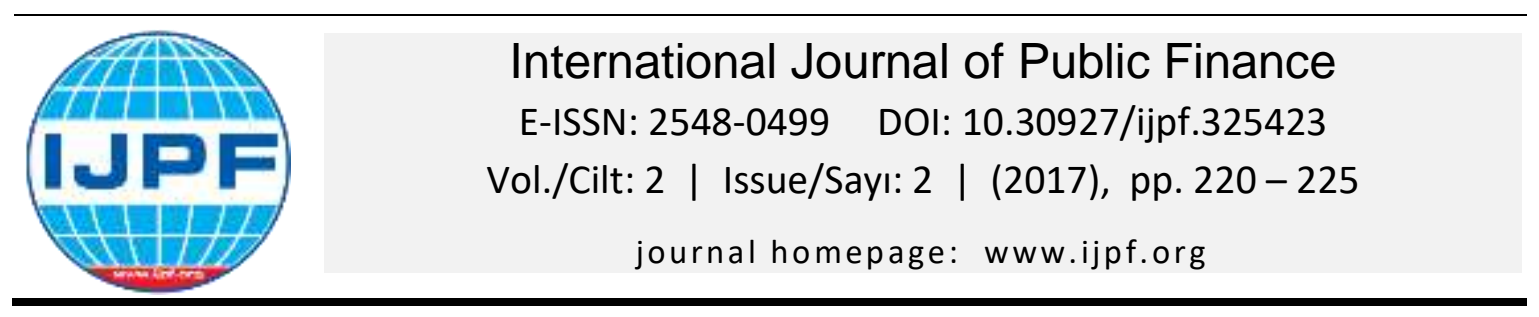

\title{
The Problem of VAT Credit on Expired Goods: An Opinion
}

\author{
Fatma TAŞ ${ }^{1}$
}

\begin{tabular}{l} 
ARTICLE INFO \\
\hline Received: 01.07 .2017 \\
Received in revised \\
form: 08.09 .2017 \\
Accepted: 24.09 .2017 \\
Available online: \\
05.01.2018 \\
\hline JEL classification: \\
K34, E62, H24
\end{tabular}

Keywords:

VAT Credit, VAT,

Turkish Tax System

\begin{abstract}
A B S T R A C T
VAT paid on certain goods acquired does not allow the deducting of the Turkish tax system. One of them is the loss of goods VAT. There is no clear definition in the law is wasted. Therefore, there are certain problems in practice.

The problems, in particular, focused on the VAT on expired or valueless goods. Current opinion on the subject of the tax administration is inconvenient regarding tax justice. Both states of the solution to the problem should be developed as well as an objective approach to protecting taxpayers.
\end{abstract}

\section{Introduction}

"All goods and services that are supplied/rendered in Turkey within the scope of commercial, industrial, agricultural, and professional activities are subject to valueadded tax (VAT). The importations of goods and services into Turkey are also subject to VAT." (KPMG, 2011: 2) The taxation of the VAT system, which aims to last consumers, the tax collected on the sale of the vendor in purchasing the credits that they have built on where they are should.

"The recently issued proposed regulations establish that a merchant that reports taxable sales of goods and services has to separately identify and calculate:

* The credit for VAT paid directly attributable to the sale of taxable goods and,

* The credit for the VAT paid directly attributable with the taxable services rendered." (rsm.global, 2016: 2)

\footnotetext{
${ }^{1}$ Assoc. Prof., Gazi University, fatma.tas@gazi.edu.tr
} 
The law did not allow the tax should in buying to be deducted in some cases. One of them is the loss of goods VAT.

Loss of value-added tax on goods subject to credit can not be made in the VAT law it is evident.

However, the concept of lost is not defined in the law. Therefore, different views among taxpayers with tax authorities in practice are emerging.

This study will focus on the VAT of expired lifetime or becomes valueless goods for various reasons.

\section{VAT Credit on Loss Goods}

\section{1. Concept of Loss Goods}

Turkish Language Society, the "loss" for one of the acts and meaning of the word has four definitions, including three adjectives.

In Turkish Tax Laws, "loss" the definition of the word is not there. This concept has been mentioned to be related partially to the goods from falling in value (Çelik, 2016: 251-252).

The Tax Procedure Law, the following expression is used in Article 278:

"Fire, because of disasters such as earthquakes and flooding or to deteriorate, rot, break, crack, corrode to such cases result in a significant decrease occurred in the economic assets..."

This phrase is very much worth a definition of a scoping nature relating to falling producer. Therefore, starting from this context, "loss" word is not possible loading means.

VAT 30/c may be descriptive about it. According to this article fire, earthquakes, natural disasters goods which do not result in such cases can not be used or considered flooding scope be lost.

Some authors "being lost" argues that the concept should not be approached not only from a physical perspective. For example, the seasonal or fashion goods connected in an impairment that occurred in a "loss" should not be considered. So, "being lost" concept must be approached from the standpoint of physical goods regarding monetary value (Kızılot, 2012: 271).

Of the other forms that may cause degradation of the goods or value must be assessed by the disappearance of the event property. Below focuses on these issues. 


\subsection{Fire, Earthquake, Flood Credit of VAT for Goods That Are Lost in Natural Disasters Such As}

According to Value Added Tax Law 30/c, "the following taxes can not be deducted:"

Lost goods (except the goods lost as a result of earthquakes, floods, and fires in the regions that are declared as force majeure by the Ministry of Finance because of fire).

As a rule, fire, flood, earthquakes and other disasters that are lost due to VAT incurred on goods used for deducting are not possible. The only exception to this is the finance ministry to declare force majeure. We also concur with this view.

The goods are partially lost (or becomes unavailable) in the case of only the part corresponding to the lost VAT will not be deducted.

\subsection{Credit of VAT on Stolen Goods}

"The process of charging VAT on supplies of goods and services requires businesses to issue VAT invoices. A VAT Invoice is a document that must be produced and issued by VAT registered businesses to provide documentary evidence of the sale of goods and services in compliance with the VAT law. A VAT Invoice is also required by the business as documentary evidence to support VAT credit claims, i.e." (Pwc, 2017: 6)

There is no explicit provision in the Turkish Tax Procedure Law of the goods stolen. When a property was stolen, it exists physically. However, the ownership of property is changing hands as unlawful. In this case, the actual owner of the goods subject to these goods to sell or in any way exploit this malt is not possible. Therefore, in any way deducting the value-added tax paid on the purchase of stolen goods it is not possible.

The VAT deducted during the purchase of goods, in return for the period was stolen "to be added VAT" written on-line discounts will be compensated.

\section{VAT Credit on Goods that are Expired or Valueless for Other Reasons}

\subsection{Different Views of the Tax Administration}

Until 2009 the tax administration had a different opinion about tax credits on goods lost. Until 2009 the concept of being lost in the views given, have been assessed as physically being there. A reduction in the value of a commodity that physically exists and may occur for various reasons. Due to reasons such as the expiration of the period of use of these technological innovations. These were not defined as goods that are the loss (Bulut, 2010:183). 
Tax administration after the date 05/12/2009 has changed its opinion on this matter. According to a new opinion; deducting the VAT should in the purchase of these goods is not possible. There isn't a clear answer to the question of why change the opinion. Given the changing views of judicial decisions in the period since the change of opinion, it must be noted that fits.

\subsection{Different Approaches in The Article Justification}

We can make use of the article justification for the scope of "goods which are lost." The justification is arranged in a way that may create confusion. The reason for this, the justification has in itself host two different approaches. These various approaches are discussed below.

\subsubsection{First Approach}

We can say that in the article justification the first approach is to prevent malicious behavior. The following were transferred to the first paragraph of justification.

"... The arrangement because the goods were lost, it is intended to prevent a tax loss that can be made. Also, the act is purposing to the taxation of the value added created in each level. From this perspective, the goods to be used for their specific needs or by the taxpayer with the withdrawal from the company there is no difference between to be lost. Therefore, the deducting of value added tax is shown on the purchase invoice for the lost goods is not possible." (TBMM, 1984: 335-336).

\subsubsection{Second Approach}

The second approach, the emphasis is on the design of the system. The second paragraph of the justification is the following.

"The most important reason for credit of the taxes paid at the time of purchase is during the sale of goods will be taxed. That is a consequence of the idea that taxing the value added goods. The lost goods shall not be sold. An added value has not to them. Therefore, deducting the tax on them would go against the logic of the system." (TBMM, 1984: 336)

\subsubsection{Analysis of The Subject}

As can be seen, different approaches are used in the article justification. The purpose of the constraint is indicated for the prevention of malicious transactions in a paragraph. However, the reason has been suggested an entirely different in the other paragraph. 
The existence of various measures is reasonable to prevent the malicious efforts of taxpayers in a tax system. However, to take place in a law contradict each other two justifications are not understood.

Two different approaches can be argued about VAT credit for this goods. According to the first paragraph of article justification, provided that the competent authority to prove in front of them stands out the meaning of the credit can be made. Moreover, this aspect was also the first opinion of the tax administration. In the past, if the Commission overseeing the destruction of the value-added tax paid on purchases of goods were made subject to credit.

When considering the second paragraph of article justification is understood that if they make not in any way subject to credit. But in this case, the problem arises regarding places declared force majeure. Because if it is declared force majeure reasons for VAT credit is made, it is inconsistent with the justification of the second paragraph.

We can give an example to explain the contradiction. Ministry of force majeure has been declared a place of VAT payers will be able to deduct it when the property loss is TL 5,000. On the other hand, a pharmaceutical warehouse it will not be able to deduct VAT when an expired drug which TL 5,000,000.

To what extent is this compatible with state tax justice? The legislator has introduced restrictions specified what purpose? The answers to these questions will be guided for the solution of the problem.

\section{Conclusion}

Value Added Tax on the loss goods that can not be deducted (except the goods wasted as a result of earthquakes, floods, and fires in the regions that are declared as force majeure by the Ministry of Finance because of fire).

The meaning of the concept should be lost; stolen goods should in the purchase of VAT credits made under any circumstances is not possible

Tax administration has two different approaches about VAT credit on goods that are expired or valueless for other reasons. When looking at the justification for solving the problem, it appears that the justification is contradictory. When accepted are not deduct VAT, it stands out regarding tax justice issues.

Correct the problem and the resolution designated for fair conditions we think should be allowed to be made a credit. In this context, the detection and destruction of goods under the supervision of a commission can be suggested. Thus, we believe that a more equitable structure formed. 


\section{REFERENCES}

Bulut, Fevzi (2010). “Kullanım Süresi Dolan Veya Benzeri Bir Nedenle Zayi Olan Malların Alımında Yüklenilen KDV'nin Akıbeti” Mali Çözüm, Sayı: 102, pp. 181-189.

Çelik, Metin (2016). "Emtia Maliyet Bedelinin Tespiti ve Değerlemesinde Önem Arz Eden Hususlar", Çözüm, Eylül-Ekim 2016.

Kızılot, Şükrü (2012). Katma Değer Vergisi Kanunu ve Uygulaması, Ankara: Yaklaşım Yayınları.

KPMG (2011). "Turkey: Country VAT/GST Essentials" https://www.kpmgvergi.com/PDF/Yayinlar/Guncel-Yayinlar/Global-IndirectTax-Turkey-Country-VATGST-Essentials.pdf.

PWC (2017). "An introduction to Value Added Tax in the GCC" https://www.pwc.com/m1/en/tax/documents/what-is-vat-faq-on-vat-in-thegcc.pdf.

RSM Global (2016). "Vat-Credit Calculation, Refund and Returns" Issue: 5, https://www.rsm.global/puertorico/sites/default/files/media/taxalerts/tax_alert_05-16.pdf

TBMM (1984)."Katma Değer Vergisi Kanunu Tasarısı ve Plan Bütçe Komisyonu Raporu" http://www.gib.gov.tr/fileadmin/mevzuatek/gerekceler/KDV/cilt_2_3065_sayili _kanun.pdf 